\title{
Habitat Features and Strategies for the Sustainable Development in the Alentejo Region
}

\author{
Rui Manuel de Sousa Fragoso ${ }^{1}$
}

\begin{abstract}
The unfavoured Portuguese regions have a level of life and economic growth rates lower than favoured regions, and the mean of European Union and hence have less entrepreneurial activities. The adoption of strategies of sustainable development driven by entrepreneurship phenomena could be a viable solution. Thus, the likely relationships between entrepreneurship and regional features were described, and sources of entrepreneurship opportunities for strategies based on the own regional resources and competitive advantages were identified. The paper concludes that, for the Alentejo region, some habitat variables should be reinforced for promoting entrepreneurship and sustainable development, and the main opportunities are related to the economic activities that belong to the regional productive profile of specialization.
\end{abstract}

Key-words: Entrepreneurship, sustainable development, strategic positioning, habitat variables.

JEL Classification: M1, M13, M2, M20.

DOI: http://dx.doi.org/10.1590/1234-56781806-94790053s01008

1. Universidade de Évora, Departamento de Gestão, CEFAGE/ICAAM, Apartado 94. 7000 Évora. Portugal. E-mail: rfragoso@uevora.pt 


\section{Introduction}

According to the Gross Domestic Production (GDP) per capita, the inner regions of Portugal have a level of life and economic growth rates lower than littoral regions and metropolitan regions of Lisbon and Porto, and below the mean of the European Union (EU).

Nowadays these territories in general have lower development levels due to falls in economic activity and employment which have led to the depopulation and hence to a clear loss of territorial competiveness and low entrepreneurial behaviour. These phenomena are not exclusive to the inner Portuguese regions and they can be observed in many EU regions and in the World. In order to attempt counteract those negative effects in the local economy and employment, the adoption of strategies of sustainable development, driven by entrepreneurship phenomena seems to be a viable solution.

The term "sustainable development" arose for the first time at the United Nations Conference on the Human Environment in 1972. Later it gained a great importance in a report to the United Nations by the World Commission on Environment and Development (WCED, 1987). Despite some controversy, sustainable development has emerged as an increasingly influential concept in managerial and settings and has become a mainstay of corporate strategy (HALL et al., 2010). Ambec \& Lanoie (2008) state that the environmental responsibility is an opportunity for increasing revenues, and indentifying some benefits from sustainability investments.

Inspired by the concept of "creative destruction" from Schumpeter (1942), some authors argue that new sustainability pressures from society have created various types of market failure, which open new opportunities to economic activity and for creating new firms (COHEN and WINN, 2007; HALL and VREDENBURG, 2003; HART and MILSTEIN, 1999; HART and CHRISTENSEN, 2002; SENGE and CARSTEDT, 2001). In this scope we can identify the entrepreneurship as a mean for profiting from opportunities of market failures such as environmental and social disruptions, in which Portuguese inner regions are very rich and can be benefited by ameliorating its competitiveness and the welfare of their populations.

Based on the concepts of sustainable development and entrepreneurship, this paper aims contributing to a better knowledge of development strategies that can be followed in less favoured territories, such as the Portuguese and Mediterranean unfavoured regions. The research question of this study is: which are the 
main regional features that can promote the entrepreneurship phenomena in the Alentejo region, southern Portugal? This question can be devised into the two following questions: 1) Which are the specific advantages of the regional habitat that can be valorised for promoting an entrepreneurial strategy? 2) Which are the regional economic activities than could offer more sustainable entrepreneurship opportunities?

In order to response to these questions, the paper describes and compares regional entrepreneurship variables and habitat variables within a more entrepreneurial context, and attempts to find sources of sustainable development strategies based on their own resources that can be driven by entrepreneurship phenomena.

The Alentejo region is a NUTS II in southern Portugal that in the European Union is classified as an unfavoured region. This region is less developed and entrepreneurial than the coastal favoured regions, but has also some important factors for the sustainable development that can be considered as interesting opportunities for entrepreneurship phenomena.

The rest of the paper is structured into five parts. Firstly we outline a brief review of the term "sustainable development" and its relationships with entrepreneurship phenomena. Then the entrepreneurship dynamics and its habitat factors are presented. The third part is devoted to the material and methods. The fourth part presents and discusses the empirical results of the case of the Alentejo NUTS II. The last part is devoted to main conclusions and remarks.

\section{Sustainable development and entrepreneurship}

According to the United Nations (WCED. 1987, p. 43), "Sustainable development is development that meets the needs of the present generation without compromising the ability of future generations to meet their own needs".
This intergenerational relationship suggests the confluence of economic, social and environmental objectives, which some authors place equally at the same level (HALL et al., 2010).

Environment and economy were considered by long time as opposed fields, where the decision taking was based on exploring the trade-offs between the objectives of the maximum economic growth and the minimum resource degradation. Recently, the introductions of economic criteria in the management of environmental resources, allowed reconcile this conflict.

The developing World is adopting development models similar to ones used by the first World in the past. However, but the Planet does not have enough resources to support equitable levels of development in all over the World. Balakishnan et al. (2003) argue a significant dampening, if not a devolution of development will be need to achieve sustainability, which means that economic growth should be reduced. Unlike, industrial and developing countries are unable for accepting reductions on economic growth, and consequently on the social well-being.

In order to attempt a response for this problem, innovation could promote many of the necessary economic and social transformations, such as firms delivering sustainable products and services. However, other authors are sceptical of existing business and believe that changes will be driven by entrepreneurs. Nowadays there is the perception that green, clean and low-carbon entrepreneurs will somehow give an important contribution for not dampen economic growth and for creating more new jobs (WWF, 2009; STERN, 2007).

The entrepreneurial economics literature offers considerable insights into how sustainable development can be achieved (KNIGHT, 1921; BAUMOL, 1990; HALL et al., 2010; PACHECO et al., 2010; YORK and VENKATATRAMAN, 2010; HOCKERTS and WÜTENHAGEN, 2010; PARRISH, 2010; KUCKERTZ and WAGNER, 2010). 


\section{The scope of entrepreneurship and habitat factors}

In many cases entrepreneurship either is associated with individual behaviour or is related to the creation and running of one's own firm (DAVIDSSON, 2005).

The importance of entrepreneurship in economic growth has become a major topic in economics after Shumpeter (1942). Since then researchersfrom differentareassuchasaccounting, finance, management, marketing, political science, psychology, and sociology have studied the relationship between entrepreneurship and economic growth (IRELAND and WEBB, 2007).

Many studies recognize firm creation as the most important driver of regional entrepreneurship and economic growth (ACS and ARMINGTON, 2004; AUDRETSCH and KEILBACH, 2005). However, the co-evolutionary theory demonstrates that an important issue that should be considered in understanding regional entrepreneurial activities is that firm birth and death are highly dependent on regional characteristics and entrepreneurial habitat (KIM et al., 2012). This theory suggests that business entities and environments influence each other and reciprocally co-evolve together and not that the entities simply adapt to their environments, as argue some studies of adaptation-selection of an organization (LEWIN and VOLBERDA, 1999; LEWIN et al., 1999; PORTER, 2006; TSAI et al., 2009).

The tendency for firms to stay in their origin region is great because its resources are established and or utilized at a local level. This geographical inertia highlights the importance of the localized networks of contacts for entrepreneurial activities and firm creation (SORENSON and AUDIA, 2000; TAMASY, 2006). Among main factors that are associated with the arising of entrepreneurship phenomena, literature presents population size, income level, number and type of Research and Development (R\&D) employees, educational degrees, university R\&D, creativity, foreign population, political structure, land costs, taxes, natural amenities, and other (ARMINGTON and ACS, 2002; AUDRETSCH and LEHMANN, 2005; BRIXY and GROTZ, 2007; KIRCHHOFF et al., 2007; LAY, 2003; LEE et al., 2004; SPILLING, 1996; WANG, 2006; WOODWARD et al., 2006).

A knowledge-based society is another importantfactorforinfluencingentrepreneurship. Among structural interpretation of regional factors, the triple helix model that characterizes university-industry-government relationships has been increasingly recognized as an important source of regional innovation that drives the transformation of scientific and technological outcomes into economic outcomes. This model has been broadly studied in the context of regional development (ETZKOWITZ et al., 2000; LEYDESDORFF et al., 2006; POWEELL and DIMAGGIO, 1991). Kim et al. (2012) investigated the determinants of entrepreneurship phenomena with basis on the interrelations among university-industry-government and conclude that the triple helix model only has influence in lower entrepreneurial or unfavoured regions, if habitat features and strategies had been established previously. Innovation is increasingly based on the interaction among the components of the triple helix model (ETZKOWITZ and ZHOU, 2007; LEYDESDORFF and VANDEN BESSELAAR, 1994).

Habitat factors define the entrepreneurial environment in which the triple helix model can be established. The main habitat factors that usually are considered in previous studies include creativity and diversity indices (LEE et al., 2004), ratio of immigrants or foreign people (KIRCHHOFF et al., 2007; SAXENIAN, 2002), crime, health care, and climate indices (GOLDSTEIN and DRUCKER, 2006) and natural amenities (WOODWARD et al., 2006). In addition, quality of life seems to be an important factor among habitat related variables (KIM et al., 2012; GOLDSTEIN and DRUCKER, 2006). 


\section{Material and methods}

In order to contribute to the purpose of this paper, a research strategy based on the case of the Alentejo region (NUTS II) in southern Portugal was adopted. Alentejo is a region near Lisbon city (140 Km by motorway) that represents one third of the Portuguese territory, but only $7 \%$ of its population. Its geographic limits are the Atlantic Ocean to the west, Spain to the east, the Tejo river to the north, and the Algarve region to the south. This is a low entrepreneurial region that represents well many Mediterranean unfavoured regions in the EU, and the challenges with which they are faced nowadays.

The method of benchmarking is used to compare variables of the Alentejo region (NUTS II) with the Lisbon region (NUTS II) and Portugal. According to EU criteria, the Lisbon region is considered a favoured European region with a GDP per capita higher than the EU27 average and hence is well suited to be considered as an entrepreneurial benchmarking by opposite to unfavoured regions, such as the Alentejo region. Then, in order to find sources of strategic opportunities for the sustainable development, the market positioning and the regional productive profile are identified with basis on regional resources and strengths.

The entrepreneurship variables are interpreted as response or dependent variables and the habitat variables are considered as the independent variables that may explain entrepreneurship phenomena. According to Kim et al. (2012), many studies use as entrepreneurship variables the birth and death rates of firms. In this case the global and sectorial firm birth rates, the firm survival rate at two years, the number of workers by created firm, and the percentage of firm birth of mean and high technology were considered. The data used are from the Indicators of Firms in 2009 (INE, 2011).

According to the literature, the habitat variables were grouped into variables of triple helix model, population and economics.
For the triple helix, in the scope of university sphere several authors use as variables university and college R\&D expenditures (ACS et al., 2002; GOLDSTEIN and DRUCKER, 2006; KINCHHOFF et al., 2007; WOODWAR et al., 2006) or the rate of people who attained university degrees in the region. In the cases of government and industry, the variables often used are government R\&D expenditures and tax rate, and venture capital investment, respectively (KIM et al., 2012; MALECKI, 1990; SPILLING, 1996). Due to the structure of the available data concerning the territorial levels of the country, NUTS II and NUTS III, we used as triple helix variables the rate of people with a university degree, the percentage of people that are enrolled in C\&T university programmes and the percentage of the Gross Added Value (GAV) from firms of mean or high technology.

Kim et al. (2012) use the natural log of state population, the natural state average annual pay and the percentage of foreign people as demographic factors. In our case we use the population size (thousand peoples), the population density, the effective growth rate of the population, and the percentage of foreign people in the population.

The economic variables are used to frame the habitat context of entrepreneurship phenomena and for assessing productivity of resources, and trends on regional productive specialization. The variables considered are the percentage of GDP in the region, the GDP per capita, work productivity, average remunerations, the human resource utilization rate, and the percentage of GAV in agriculture and extractive activities, industry and building and commerce, and services.

The regional strategic positioning is given by the regional market positioning of the region and by its regional productive profile.

The market positioning depends on the regional competitive advantage (CA) and market position in terms of the international commerce. The competitive advantage represents the advantage of the region $a$ (Alentejo) for a given 
activity $j$ in terms of the international commerce, and can be determined by the following indicator:

$$
\mathrm{CA}_{\mathrm{ja}}=\frac{\mathrm{X}_{\mathrm{ja}}}{\mathrm{X}_{\mathrm{a}}} \times \frac{\mathrm{X}_{\mathrm{p}}}{\mathrm{X}_{\mathrm{jp}}}
$$

In which $X$ are the exports, the index $p$ is related to the reference territory (Portugal). A CAja greater than 1 means that the activity $j$ in the region $a$ has a competitive advantage over the reference territory (Portugal).

The market position (MP) reveals the market share of a regional activity in a broadly context, which in our case are the Portuguese exports. This indicator is obtained for a given activity at regional level from the respective net balance between exports and imports divided by total exports of the activity:

$$
\mathrm{MP}_{\mathrm{ja}}=\frac{X_{\mathrm{ja}}-\mathrm{W}_{\mathrm{ja}}}{\mathrm{X}_{\mathrm{jp}}}
$$

In which $X$ and $W$ are the exports and imports, respectively.

Thus, considering the possible results of $C A$ and $M P$ we have the following four market positioning: i) markets with competitive advantage and positive market position; ii) markets with competitive advantage and negative market position; iii) markets without competitive advantage and negative market position; markets without competitive advantage and positive market position;

The regional productive profile is the productive specialization of a region in which are relevant opportunities for entrepreneurship phenomena that can be carried out in a context of sustainable development. These are indentified considering the coefficient of localization and the share they have in employment, as follows:

$$
\mathrm{QL}_{\mathrm{ja}}=\frac{\mathrm{Y}_{\mathrm{ja}}}{\mathrm{Y}_{\mathrm{a}}} \times \frac{\mathrm{Y}_{\mathrm{p}}}{\mathrm{Y}_{\mathrm{jp}}}
$$

In which $Y$ could be turnover or employment, and $j, a$ and $p$ are relative to the economic activity, region (Alentejo) and reference territory (Portugal), respectively. A $Q L$ equal to zero means that the activity $j$ does not exist in the region $a$ and a $Q L$ equal to 1 means that the regional specialization degree is equal to the one of the reference territory. A $Q L$ greater than 1 indicates that the region $a$ is more specialized than the reference territory $p$ for producing the activity $j$.

In order to find the regional productive specialization we consider the economic activities that have simultaneously a $Q L$ greater than 1 and represent more than $1 \%$ of the regional employment.

\section{Empirical results}

Table 1 presents entrepreneurship and habitat variables for Portugal and NUTS II of Lisbon and Alentejo, from which we can do some interesting observations.

Concerning entrepreneurship variables, firm birth rate in Alentejo (14.95\%) is very similar to the Portuguese average $(15.09 \%)$ and $12 \%$ less than the Lisbon region. The proportion of births firms of mean and high technology in the Lisbon region (2.75) is almost double of the Alentejo and $40 \%$ more than the Portuguese average. Firm survival rate after 2 years in Alentejo is $49.52 \%$, this is, very close to the Portuguese value $(49.36 \%)$, while in Lisbon it is only $44.96 \%$.

All triple helix variables in Alentejo present lower levels than ones of Lisbon and Portugal. For instance the GAV associated to firms of mean and high technology in Alentejo is only $3.79 \%$, this is, five times less than in Lisbon and a tier of Portugal. These suggest that the regional strategy of the triple helix should be redefined in order that the activity of university organizations be more focused on the regional sustainable development problems, and for promoting more entrepreneurial activities.

Alentejo represents only 7\% of the Portuguese population, while this percentage in Lisbon exceeds $25 \%$. The population density is very low (23.7 people/ $\left.\mathrm{Km}^{2}\right)$, compared to Lisbon (946 people $/ \mathrm{Km}^{2}$ ) and Portugal (115.4 people/ $\left./ \mathrm{Km}^{2}\right)$. In addition to being lowly populated, Alentejo's population is also aged with a higher percentage 
Table 1. Entrepreneurship and habitat variables for Portugal and NUTS II of Lisbon and Alentejo

\begin{tabular}{|c|c|c|c|c|}
\hline & Units & Portugal & Lisboa & Alentejo \\
\hline \multicolumn{5}{|l|}{ Entrepreneurship variables } \\
\hline Firm birth rate & $\%$ & 15.09 & 16.88 & 14.95 \\
\hline Firm birth rate in processing industry & $\%$ & 7.67 & 9.02 & 7.54 \\
\hline Firm birth rate in building & $\%$ & 10.54 & 12.61 & 11.11 \\
\hline Firm birth rate in commerce and services & $\%$ & 16.33 & 17.62 & 16.07 \\
\hline Firm survival rate after 2 years & $\%$ & 49.36 & 44.96 & 49.52 \\
\hline Average workers at firm birthed & № & 1.28 & 1.24 & 1.22 \\
\hline Proportion of firms births of mean and high technology & $\%$ & 1.96 & 2.75 & 1.42 \\
\hline \multicolumn{5}{|l|}{ Triple helix variables } \\
\hline Gross Added Value in firms of mean and high technology & $\%$ & 10.62 & 15.34 & 3.79 \\
\hline Rate of people with an university degree & $\%$ & 31.5 & 44.9 & 21.3 \\
\hline People enrolled in university C\&T programmes & $\%$ & 28.9 & 28.5 & 21.5 \\
\hline \multicolumn{5}{|l|}{ Population variables } \\
\hline Population size & 1000 people & 10.636 .979 & 2.839 .908 & 749.055 \\
\hline Population density & people $/ \mathrm{Km}^{2}$ & 115.4 & 946 & 23.7 \\
\hline Population effective growth rate & $\%$ & -0.01 & 0.32 & -0.58 \\
\hline Population between $0-14$ years old & $\%$ & 15.11 & 16.25 & 13.33 \\
\hline Population between $15-24$ years old & $\%$ & 10.93 & 9.96 & 9.88 \\
\hline Population between $25-64$ years old & $\%$ & 55.80 & 55.76 & 53.67 \\
\hline Population with more than 65 years old & $\%$ & 18.16 & 18.03 & 23.12 \\
\hline Proportion of foreign population & $\%$ & 4.17 & 7.79 & 3.56 \\
\hline \multicolumn{5}{|l|}{ Economic variables } \\
\hline Percentage of Gross Domestic Production - GDP & $\%$ & 100.0 & 37.1 & 6.5 \\
\hline GDP per capita & 1000 Euros & 16.19 & 22.71 & 14.85 \\
\hline Firm density & №/ $/ \mathrm{Km}^{2}$ & 11.5 & 108.3 & 2.1 \\
\hline Work productivity & 1000 Euros & 47.43 & 46.09 & 51.39 \\
\hline Average remunerations & 1000 Euros & 19.50 & 23.70 & 18.20 \\
\hline Human resources utilization rate & $\%$ & 48.39 & 52.33 & 41.63 \\
\hline Gross Added Value in agriculture and extractive activities & $\%$ & 2.4 & 0.4 & 9.4 \\
\hline Gross Added Value in industry and building & $\%$ & 24.6 & 16.9 & 28.2 \\
\hline Gross Added Value in commerce and services & $\%$ & 73.0 & 82.7 & 62.4 \\
\hline
\end{tabular}

Source: INE (2011).

of dependent people and a lower percentage of people in active age than in Lisbon and Portugal. The population effective growth rate in Alentejo is negative $(-0.58 \%)$ showing that in the last decade the region was unattractive compared to other Portuguese regions. Another indicator used for assessing the entrepreneurial habitat is the proportion of foreign people in the population. Alentejo presents also the lowest value (3.56\%), which is $85 \%$ and $45 \%$ of the values of Portugal and Lisbon, respectively.

In economic terms Alentejo represents $6.5 \%$ of Portuguese GDP, which is almost its contribution for the population. However,
Lisbon, represents $26 \%$ of population and $37.1 \%$ of the GDP. In addition, the GDP per capita in Alentejo (14.85 thousand euros) shows a level of life below Lisbon (22.71 thousand euros) and the Portuguese average (16.19). These results can be partially explained by the low firm density in Alentejo (2.1 firms $/ \mathrm{Km}^{2}$ ), when compared with Portugal (11.5 firms/ $/ \mathrm{Km}^{2}$ ) and Lisbon (108.3 firms/ $\mathrm{Km}^{2}$ ).

In Alentejo work productivity is $11 \%$ and $8 \%$ higher than in Lisbon and Portugal, and wages are $23 \%$ and $7 \%$ lower, respectively. The highest work productivity and the lowest average remunerations can be a competitive advantage 
for entrepreneurship phenomena, namely at the level of new firm creation. Despite some revealed competiveness in the work factor, the human resources utilization rate in Alentejo is only $41.63 \%$, this is, $20 \%$ and $14 \%$ less than in Lisbon and Portugal, respectively. The GAV per economic sector shows for the Alentejo NUTS II a high importance of agriculture and extractive activities $(9.4 \%)$ and industry and building activities $(28.2 \%)$, and a minor importance of commerce and service activities $(62,4 \%)$. In Portugal and Lisbon, agriculture and extractive activities only represent $0.4 \%$ and $2.4 \%$ of GAV, but commerce and services has the majority of the GAV, representing $82.7 \%$ and $73 \%$, respectively.

Table 2 presents the market positioning indicators in terms of the international commerce for the Alentejo NUTS II.

The economic activities that have the best market positioning are those that have a competitive advantage and a positive market position, which are in the case of the Alentejo
NUTS II the following: vegetable products; product of food industries, beverages, tobacco and others; mineral products; products of chemical industries; and plastics and rubber articles. These activities present a market positioning more favourable than the Portuguese context, once they benefit from a regional competitive advantage and from a competitive position in markets. So these activities may be associated to the best opportunities for entrepreneurship, because they are competitive and less exposed to competition, and have a good potential for creating more value added.

Economic activities with competitive advantage, but with a negative market position are in Alentejo: live animals and animal products; and hides, leather, articles of travel bags and others. In these activities the Alentejo NUTS II has a competitive advantage expressed by a proportion of exports greater than Portugal.

With a positive market position, but without a competitive advantage we can find the following economic activities: wood, cork and articles, and basketry; articles of stone, ceramic, and glass; optical,

Table 2. Market positioning in the international commerce of Alentejo NUTS II

\begin{tabular}{lcc}
\hline & Competive advantage & Market position \\
\hline Live animals and animal products & 1.0 & -3.1 \\
Vegetable products & 3.8 & 5.5 \\
Animal or vegetable fats and oils waxes and others & 0.8 & 2.4 \\
Products of food industries, beverages, tobacco and others & 1.7 & 5.7 \\
Mineral products & 2.9 & 7.1 \\
Products of chemical industries & 2.5 & 7.7 \\
Plastics and rubber articles & 2.2 & 8.9 \\
Hides, leather, articles of travel, bags and others & 1.2 & -2.5 \\
Wood, cork and articles, and basketry & 0.5 & 1.9 \\
Wood pulp, paper and paperboard articles & 0.1 & -0.4 \\
Textiles and textile works & 0.2 & -0.5 \\
Shoes, hats, umbrellas, canes and others & 0.0 & -0.2 \\
Articles of stone, ceramic, and glass & 0.6 & 2.5 \\
Pearls, precious metals, jewellery, coins & 0.0 & -2.4 \\
Base metals and articles & 0.4 & -1.8 \\
Machinery and electrical equipment & 0.8 & 0.1 \\
Transport equipment & 0.2 & -12.5 \\
Optical, photo, watches and others & 0.6 & 1.1 \\
Arms and ammunition. parts and accessories & 0.0 & -1.0 \\
Merchandises and diverse products & 0.4 & 2.2 \\
Works of art, collectors' pieces and antiques & 0.0 & 0.2 \\
\hline
\end{tabular}

Source: INE (2011). 
photo, watches and others; and merchandises and diverse products. The Alentejo NUTS II does not have a competitive advantage in these economic activities, because its exports are proportionally lower than in Portugal. However, the market position reveals that there is a good demand for products, which may also be an entrepreneurship opportunity.

Remaining activities are few competitive because, both regional imports are greater that exports and there are other regions in Portugal with more competitive advantages that produce the products better.

The regional productive specialization is defined by economic activities that have a coefficient of localization greater than 1 and a weight on the regional employment greater than $1 \%$. Table 3 presents the employment structure and the coefficient of localization in the Alentejo NUTS II by economic activity.

The Alentejo NUTS II has a very strong position into the production of activities from the branch of agriculture, forest and fisheries given its high value of the coefficient of localization $(\mathrm{QL}=8.7)$ and the weigh on the regional employment (12.1\%). Extractive industries have also a great regional specialization degree with a QL equal to 11.6 and represent $1.4 \%$ of the regional employment. Manufacturing industries have an important weight in the regional employment (20.2\%) and reveal a QL of 1.4. Accommodation, catering and similar are economic activities that are associated to the tourism industry, and in Alentejo represents $6.6 \%$ of employment and has a degree of specialization $30 \%$ higher than in Portugal $(\mathrm{QL}=1.3)$.

The regional specialization degree is also high in the activities from the branch of administration, defence and compulsory social security, which present a QL of 5.2\% and a weight of $2.3 \%$ in the regional employment structure. The wholesale and retail trade, repair of vehicles and motorcycles, which represent an important set of service and commerce activities, show in Alentejo a degree of specialization similar to Portugal, as well as, its weight in the employment.

Table 3. Market positioning in the international commerce of Alentejo NUTS II

\begin{tabular}{lcc}
\hline & Competive advantage & Market position \\
\hline Live animals and animal products & 1.0 & -3.1 \\
Vegetable products & 3.8 & 5.5 \\
Animal or vegetable fats and oils waxes and others & 0.8 & 2.4 \\
Products of food industries, beverages, tobacco and others & 1.7 & 5.7 \\
Mineral products & 2.9 & 7.1 \\
Products of chemical industries & 2.5 & 7.7 \\
Plastics and rubber articles & 2.2 & 8.9 \\
Hides, leather, articles of travel, bags and others & 1.2 & -2.5 \\
Wood, cork and articles, and basketry & 0.5 & 1.9 \\
Wood pulp, paper and paperboard articles & 0.1 & -0.4 \\
Textiles and textile works & 0.2 & -0.5 \\
Shoes, hats, umbrellas, canes and others & 0.0 & -0.2 \\
Articles of stone, ceramic, and glass & 0.6 & 2.5 \\
Pearls, precious metals, jewellery, coins & 0.0 & -2.4 \\
Base metals and articles & 0.4 & -1.8 \\
Machinery and electrical equipment & 0.8 & -12.5 \\
Transport equipment & 0.2 & 1.1 \\
Optical, photo, watches and others & 0.6 & -1.0 \\
Arms and ammunition. parts and accessories & 0.0 & 2.2 \\
Merchandises and diverse products & 0.4 & 0.2 \\
Works of art, collectors' pieces and antiques & 0.0 & \\
\hline
\end{tabular}

Source: INE (2011). 


\section{Conclusion}

In this paper, we studied how the Alentejo region in southern Portugal can profit from entrepreneurship phenomena for achieving a sustainable development. The likely relationships between entrepreneurship and regional features were described, and strategies based on the own regional resources and competitive advantages were identified as opportunities for entrepreneurship phenomena.

Results showed that the Alentejo NUTS II, has, less entrepreneurial activities than Portugal and the Lisbon NUTS II, but the firm survival rate after two years is greater. The less entrepreneurial activities in the Alentejo NUTS II are clearly explained by low performance of triple helix, population and economic variables. However, there are some habitat variables that may help to raise more entrepreneurial activities in the Alentejo NUTS II, such as good levels of work productivity and the proportion of people enrolled in university C\&T programmes, and lower wages and scale and scope economies in some sectors related with production of tradable goods.

Another interesting conclusion that results suggest, is the need for redefining the regional triple helix strategy in order for it to become more focused in regional values and competitive advantages, namely in terms of I\&D and technology transfer.

The economic strategic positioning of the Alentejo NUTS II leads us to conclude that agribusiness, tourism business and other business in activity braches related to specific social and environmental disruptions are important sources of entrepreneurship commons to the entire region. In addition there are other economic activities associated to specific local resources, skills, and economic and social relationships, such as the cases of direct foreign investment in manufacturing industries of mean and high technology, the University of Évora, people enrolled in C\&T programmes, the industrial complex of Sines in the Alentejo Litoral NUTS
III, or the strong specialization in extractive industries.

Results and conclusions for the Alentejo region give interesting highlights for promoting strategies of sustainable development driven by entrepreneurship phenomena in other Portuguese and Mediterranean regions.

\section{References}

ACS, Z. J. and ARMINGTON, C. Employment growth and entrepreneurship activity in cities. Regional Studies, v. 38, p. 911-927, 2004.

ACS, Z. J., ANSELIN, L. and VARGA, A. Patents and innovation counts as measures of regional production of new knowledge. Research Policy, v. 31, p. 1069-1085, 2002.

AMBEC, S. and LANOIE, P. Does it pay to be green? A systematic overview. Academy of Management Perspectives, v. 22, n. 4, p. 45-62, 2008.

ARMINGTON, C. and ACS, Z. J. The determinants of regional variation in new firm formation. Regional Studies, v. 36, p. 33-45, 2002.

AUDRETSCH, D. B. and KEILBACH, M. Entrepreneurship capital and regional growth. Annals of Regional Science, v. 39, p. 457-469, 2005.

AUDRETSCH, D. B. and LEHMANN, E. E. Does the knowledge spillover theory of the entrepreneurship hold for regions? Research Policy, v. 34, p. 1191-1202, 2005.

BALAKISHNAN, U., DUVALL, T. and PRIMEAUX, P. Rewriting the bases of capitalism: reflexive modernity and ecological sustainability as the foundations o a new normative framework. Journal of Business Ethics, v. 47, n. 4, p. 299-315, 2003.

BAUMOL, W. Entrepreneurship: productive, unproductive, and destructive. Journal of Political Economy, v. 98, n. 5, p. 893-921, 1990.

BRIXY, U. and GROTZ, R. Regional patterns and determinants of birth and survival of new firms in Western Germany. Entrepreneurship and Regional Development, v. 19, p. 293-312, 2007.

COHEN, B. and WINN, M. L. Market imperfections, opportunity and sustainable entrepreneurship. Journal of Business Venturing, v. 22, n. 1, p. 29-49, 2007.

DAVIDSSON, P. Researching Entrepreneurship. New York: Springer, 2005. 
ETZKOWITZ, H. and ZHOU, C. Regional innovation initiator: the entrepreneurial university in various triple helix models. In: Triple Helix 6 th Conference Theme Paper, Singapure, 2007.

ETZKOWITZ, H., WEBSTER, A., GEBHARDT, C. and TERRA, B. R. C. The future of the university and the university of the future: evolution of ivory tower to entrepreneurial paradigm. Research Policy, v. 29, p. 313330, 2000.

GABINETE DE ESTRATÉGIA E PLANEAMENTO (GEP) Quadros de Pessoal 2008. Ministério do Trabalho e da Solidariedade Social, 2008.

GOLDSTEIN, H. and DRUCKER, J. The economic development impacts of universities on regions: do size and distance matter? Economic Development Quarterly, v. 20, p. 22-43, 2006.

HALL, J. K., DANEKE, G. A. and LENOX, M. J. Sustainable development and entrepreneurship: Past contributions and future directions. Journal of Business Venturing, v. 25, p. 439-448, 2010.

HALL, J. K. and VREDENBURG, H. The challenges of innovation for sustainable development. Sloan Management Review, v. 45, n. 1, p. 61-69, 2003.

HART, S. and CHRISTENSEN, C. The Great Leap: driving innovation from the base of the pyramid. MIT Sloan Management Review, v. 44, n. 1, p. 51-56, 2002.

HART, S. and MILSTEIN, M. Global sustainability and the creative destruction of industries. Sloan Management Review, v. 41, n. 1, p. 23-33, 1999.

HOCKERTS, K. and WÜTENHAGEN, R. Greening Goliaths versus emerging Davids - Theorizing about the role of incumbents and new entrants in sustainable entrepreneurship. Journal of Business Venturing, v. 25, n. 5, p. 481-492, 2010.

INSTITUTO NACIONAL DE ESTATÍSTICA (INE) Statistical Yearbool of Alentejo Region in 2010, 2011.

IRELAND, R. D. and WEBB, J. W. A cross-disciplinary exploration of entrepreneurship research. Journal of Management, v. 33, p. 891-927, 2007.

KIM, Y., KIM, W. and YANG, T. The effect of the triple helix system and habitat on regional entrepreneurship: Empirical evidence from US. Research Policy, v. 41, p. 154-166, 2012.

KNIGHT, F. H. Risk, Uncertainty, and Profit. Boston, MA: Houghton Mifflin, 1921.

KIRCHHOFF, B. A., NEWBERT, S. L., HASAN, I. and ARGMINGTON, C. The influence of university R\&D on new business formations and employment growth. Entrepreneurship Theory and Practice, v. 31, p. 543-559, 2007.

KUCKERTZ, A. and WAGNER, M. The influence of sustainability orientation on entrepreneurial intentions - investigating the role of business experience. Journal of Business Venturing, v. 25, n. 5, p. 524-539, 2010.

LAY, T. J. The determinants of the interaction between entry and exist in Taiwan's manufacturing. Small Business Economics, v. 20, p. 319-334, 2003.

LEE, S. Y., FLORIDA, R. and ACS, Z. J. Creativity and entrepreneurship: a regional analysis of new firm formation. Regional Studies, v. 38, p. 879-891, 2004.

LEWIN, A. Y., LONG, C. P. and CARROLL, T. N. The coevolution of new organizational forms. Organization Science, v. 10, p. 535-550, 1999.

LEWIN, A. Y. and VOLBERDA, H. W. Prolegomena on coevolution: a framework for research on strategy and new organizational forms. Organization Science, v. 10, p. 519-534, 1999.

LEYDESDORFF, L., DOLSFSMA, W. and VAN DER PANNE, G. Measuring the knowledge base of an economy in terms of triple-helix relations among technology, organization and territory. Research Policy, v. 35, p. 181-199, 2006.

LEYDESDORFF, L. and VANDEN BESSELAAR, P. Evolutionary Economics and Chaos Theory: New Directions in Technology Studies. New York: St. Martin's Press, 1994.

MALECKI, E. J. New firm formation in the USA: corporate structure, venture capital, and local environment. Entrepreneurship and Regional Development, v. 2, p. 247-265, 1990.

PACHECO, D. F., DEAN, T. J. and PAYNE, D. S. Escaping the green prision: Entrepreneurship and the creation of opportunities for sustainable development. Journal of Business Venturing, v. 25, n. 5, p. 464-480, 2010.

PARRISH, B.D. Sustainability-driven entrepreneurship: Principles of organization design. Journal of Business Venturing, v. 25, n. 5, p. 510-523, 2010.

PORTER, T. B. Coevolution as a research framework for organizations and the natural environment. Organization Environment, v. 19, p. 479-504, 2006.

POWEELL, W. W. and DIMAGGIO, P. J. The New Institutionalism in Organizational Analysis. Chicago: University Press, 1991.

SAXENIAN, A. Silicon Valley's new immigrant highgrowth entrepreneurs. Economic Development Quarterly, v. 16, p. 20-31, 2002. 
SENGE, P. and CARSTEDT, G. Innovating our way to the next industrial revolution. Sloan Management Review, v. 42, n. 2, p. 24-38, 2001.

SHUMPETER, J.A. Capitalism, Socialism and Democracy. New York: Harper and Row, 1942.

SORENSON, O. and AUDIA, P. G. The social structure of entrepreneurial activity: geographic concentration of footwear production in the United States, 19401989. American Journal of Sociology, v. 106, p. 424-461, 2000.

SPILLING, O. R. Regional variation of new firm formation: the Norwegian case. Entrepreneurship and Regional Development, v. 8, p. 217-243, 1996.

STERN, N. The Economics of Climate: The Stern Review. London: The Cambridge University Press, 2007.

TAMASY,C. Determinants of regional entrepreneurship dynamics in contemporary Germany: a conceptual and empirical analysis. Regional Studies, v. 40, p. 365$384,2006$.
TSAI, F. S., HSIEH, L. H. Y., FANG, S. C. and LIN, J. L. The co-evolution of business incubation and national innovation systems in Taiwan. Technological Forecasting and Social Change, v. 76, p. 629-643, 2009.

WANG, S. W. Determinants of new firm formation in Taiwan. Small Business Economics, v. 27, p. 313-321, 2006.

WORLD COMMISSION ON ENVIRONMENT AND DEVELOPMENT (WCED) Our Common Future. New York: Oxford University Press, 1987

WOODWARD, D., FIGUEIREDO, O. and GUIMARÃES, P. Beyond Silcon Valley: university R\&D and hightechnology location. Journal of Urban Economics, v. 60, p. 15-32, 2006.

WWF Low Carbon Jobs for Europe. London: World Wide Fund for Nature, 2009.

YORK, J.G. and VENKATATRAMAN, S. The entrepreneur-environment nexus: Uncertainty, innovation, and allocation. Journal of Business Venturing, v. 25, n. 5, p. 449-463, 2010. 